\title{
Achieving high uptake of human papillomavirus vaccination in Malaysia through school-based vaccination programme
}

Nor Asiah Muhamad ${ }^{1,5^{*}}$, Saidatul Norbaya Buang ${ }^{2 \dagger}$, Safurah Jaafar ${ }^{3,2}$, Rohani Jais ${ }^{5}$, Phaik Sim Tan², Normi Mustapha ${ }^{4}$, Noor Aliza Lodz', Tahir Aris ${ }^{1}$, Lokman Hakim Sulaiman ${ }^{3,6}$ and Shahnaz Murad ${ }^{7}$

\begin{abstract}
Background: In 2006, 4 years of planning was started by the Ministry of Health, Malaysia (MOH), to implement the HPV (human papillomavirus) vaccination programme. An inter-agency and multi-sectoral collaborations were developed for Malaysia's HPV school-based immunisation programme. It was approved for nationwide school base implementation for 13-year-old girls or first year secondary students in 2010. This paper examines how the various strategies used in the implementation over the last 7 years (2010-2016) that unique to Malaysia were successful in achieving optimal coverage of the target population.

Methods: Free vaccination was offered to school girls in secondary school (year seven) in Malaysia, which is usually at the age of 13 in the index year. All recipients of the HPV vaccine were identified through school enrolments obtained from education departments from each district in Malaysia. A total of 242,638 girls aged between 12 to 13 years studying in year seven were approached during the launch of the program in 2010. Approximately 230,000 girls in secondary schools were offered HPV vaccine per year by 646 school health teams throughout the country from 2010 to 2016.

Results: Parental consent for their daughters to receive HPV vaccination at school was very high at $96-98 \%$ per year of the programme. Of those who provided consent, over 99\% received the first dose each year and 98-99\% completed the course per year. Estimated population coverage for the full vaccine course, considering also those not in school, is estimated at 83 to $91 \%$ per year. Rates of adverse events reports following HPV vaccination were low at around 2 per 100,000 and the majority was injection site reactions.

Conclusion: A multisectoral and integrated collaborative structure and process ensured that the Malaysia schoolbased HPV immunisation programme was successful and sustained through the programme design, planning, implementation and monitoring and evaluation. This is a critical factor contributing to the success and sustainability of the school-based HPV immunisation programme with very high coverage.
\end{abstract}

Keywords: Cervical cancer, Immunisation, HPV, School based, Malaysia

\footnotetext{
* Correspondence: norasiahdr@gmail.com

${ }^{\dagger}$ M. Nor Asiah and B. Saidatul Norbaya contributed equally to this work.

${ }^{1}$ Institute for Public Health, Ministry of Health, Kuala Lumpur, Malaysia

${ }^{5}$ Disease Control Division, Ministry of Health, Kuala Lumpur, Malaysia

Full list of author information is available at the end of the article
}

(c) The Author(s). 2018 Open Access This article is distributed under the terms of the Creative Commons Attribution 4.0 International License (http://creativecommons.org/licenses/by/4.0/) which permits unrestricted use, distribution, and reproduction in any medium, provided you give appropriate credit to the original author(s) and the source, provide a link to the Creative Commons license, and indicate if changes were made. The Creative Commons Public Domain Dedication waiver (http://creativecommons.org/publicdomain/zero/1.0/) applies to the data made available in this article, unless otherwise stated. 


\section{Background}

HPV is the commonest sexually transmitted infection (STI) $[1,2]$. HPV infection is associated with various health problems such as genital warts, cancers of male and female genitalia and of the oropharynx [2-4]. These double-stranded deoxyribonucleic acid (DNA) viruses are the main causative agents in cervical intraepithelial neoplasia and cancer [5]. HPV genotypes 16 and 18 have been established to cause $70 \%$ of cervical malignancies in women $[2,6]$.

\section{Cervical cancers incidence}

Cervical cancer is the second most frequent cancer in the low-income countries and fourth in the world [7].It is the most common malignant cancer of the female reproductive organs $[8,9]$. Globally, the incidence of cervical cancer is estimated to be at 500,000 cases with 300,000 deaths yearly. About $80-85 \%$ of these cases occur in developing countries [9-11]. In Malaysia, cervical cancer is the second most frequently occurring cancer (after breast cancer) amongst women aged 1544 years [12]. Between 2007 and 2011, a total of 4352 new cases of cervical cancer were reported by the National Cancer Registry. Of these cases, 34.5\% occurred among women aged 50-59 years and $64.4 \%$ were detected at stage 1 and $2[13,14]$.

\section{Screening and prevention for cervical cancer}

Various strategies for prevention have been developed including vaccination, cervical cytology (Pap testing), and HPV DNA based screening, for early detection and effective treatment. HPV vaccines covering HPV16 and 18 can prevent up to $70 \%$ of cervical cancer cases without screening $[15,16]$. Early screening and detection will significantly increase the chance of survival as the cellular changes are detected earlier and the treatment can commence immediately [17]. Since HPV vaccination was introduced in 2006, more than 71 countries have adopted HPV vaccination as a primary strategy for the prevention of cervical cancer [18]. The HPV Immunisation Programme in Malaysia was launched in August 2010 and added to the list of the National Immunisation Programme, which provides selected vaccines free of charge to all residents as a public health service [19]. The population of Malaysia in 2016 was approximately 32 million comprising predominantly Malay, Chinese, Indian and others, including indigenous groups in Peninsular Malaysia and the native people of East Malaysia, as compared to 32.2 million in 2017, with an annual population growth rate of $1.1 \%$ with most people residing in suburban and rural areas [20].A study done by Cheong et al. [21] and Norrafizah et al. [22] showed that people in rural areas and with low socio-economic status have poorer health literacy.

\section{Screening practices in Malaysia}

Prior to 2010, cytology-based screening was the main preventive measure for cervical cancer in Malaysia. The Papanicolaou smear (Pap smear) screening services initially aimed at post-partum mothers in family planning programs. In 1995, Pap smear screening was expanded to women aged between 20 to 65 years [23]. Despite the availability and promotion campaign on screening services nationwide, the uptake rates were only $26 \%$ in 1996 and 43.7\% in 2006 [24]. Lack of knowledge about the disease, inadequate health literacy, low perception of cancer risk, behaviour and attitude towards the preventive programme and lack of systematic, population based, active recruitment approaches to women were the factors that contributed to the low percentage of women seeking and receiving the service [21, 22, 25]. Therefore, an HPV vaccination programme was developed for school girls in Malaysia as part of its cancer prevention strategy.

The HPV vaccines became available in 2006 [26]. Since then, efforts were initiated to introduce the HPV vaccination in Malaysia. The vaccines (Gardasil and Cervarix) were registered for private market use in 2006 and 2010 respectively for women aged 9 to 40 years $[27,28]$. The introduction of HPV vaccination was projected to prevent $89 \%$ of cervical cancer caused by HPV 16 and HPV 18 [29] and save substantial annual costs for HPV related treatments [30, 31].

The Ministry of Health $(\mathrm{MOH})$, through the school-based services, has introduced the HPV vaccination program for school girls at age 13. The school health service package provides school-based services from preschool until age 15 as shown in Table 1. The HPV vaccination program is projected to reduce occurrence of the cervical cancer incidence associated with HPV16 \& 18 among immunised girls in next 20 years. This paper aims to describe the new policy and model for delivery of HPV vaccination, and the initial experiences and results from pilot implementation from the Malaysian school base HPV program vaccination and factors contributing to its successful implementation over the last 6 years.

\section{Vaccination schedule}

Intramuscular injection of 3 doses of quadrivalent HPV vaccine delivered on a standard dosing schedule (at 0, 2, and 6 months).From 2010 to 2014, each recipient received 3 doses of HPV vaccine at the interval of 0,1 and 6 months. However, in 2015 following the guideline from the World Health Organization (WHO), two doses of HPV vaccine were introduced under the new policy where by these doses of vaccine were given at 0 - and 6-monthsinterval [32, 33]. This school base grade cohort approach was preferred, as it clearly defined the target 
Table 1 Package of school health services in $\mathrm{MOH}$

\begin{tabular}{|c|c|}
\hline Grade \& Age & Service Package \\
\hline Pre school & Growth and development Assesment \\
\hline Standard 1 (age 7) & $\begin{array}{l}\text { • Health Education, Health } \\
\text { Appraisal, Vision screening, } \\
\text { BMl Monitoring } \\
\text { Immunization Measles Rubella } \\
\text { (MR) and Diphtheria } \\
\text { Tetanus (DT) Booster dose) }\end{array}$ \\
\hline Standard 3 (age 7) & $\begin{array}{l}\text { Learning Disability } \\
\text { Assessment and Confirmation }\end{array}$ \\
\hline Standard 6 (age 11) & $\begin{array}{l}\text { - Health Education, Health } \\
\text { Appraisal; Vision screening; } \\
\text { BMI Monitoring and } \\
\text { - Scoliosis screening }\end{array}$ \\
\hline Form 1 (girls age 13) & · HPV Immunization \\
\hline Form 3 (age 15) & $\begin{array}{l}\text { - Health Education, Health Appraisal, } \\
\text { Vision screening, BMI Monitoring and } \\
\text { - Color Defect Screening; ATT } \\
\text { Booster Immunization }\end{array}$ \\
\hline Form 4 (age 16) & - Thalassaemia Screening \\
\hline
\end{tabular}

Source: Family Health Department, Ministry of Health Malaysia 2018

population and allowed precise estimates of vaccine doses and consumables required to be procured.

\section{Methods \\ Description of process on HPV vaccination program Integration of HPV vaccination into National Immunisation and school health services}

High rates of school enrolment for 13-year olds (96.0\%) and retention of female students in secondary schools have made it possible for the HPV vaccination to be integrated into the School Health Service Program and ensures equal access to the HPV vaccine between urban and rural area $[20,24]$.

\section{$\mathrm{MOH}$ Organisational infrastructure}

At the onset of the launch, 450 school's health teams were readily available to deliver the services throughout the country for both public and private schools. To ensure the 3 doses of vaccination were able to be delivered within the set time frame, the nurses from the various $\mathrm{MOH}$ health clinics were mobilised to support the school health teams.

\section{Reporting}

The progress of implementation on the level of consent and coverage of immunization were reported to National Policy and Practices on Immunisation committee regularly. The year seven female students' enrolment data were obtained from District Education departments at the end of the year and later verified with schools' enrolment lists.

\section{Program monitoring}

The most crucial factor that determines supporting high vaccination coverage was program monitoring. The $\mathrm{Na}$ tional, State and districts HPV Operation Rooms were set-up to closely monitor the implementation at all implementation levels. The operation room was spearheaded by the Director of the Family Health Development Division, with support from various technical officers responsible for technical documentation of the progress, adverse reactions, public enquiries, ICT requirements and daily operations. All public enquiries on the HPV immunization were responded to by a Public Health Physician and paramedics that were put on-call on a rotational basis to answer the hotlines from the public as well as any queries from implementers at school or health clinics.

\section{Program approach}

The National School based HPV Immunisation Program was implemented in 2958 public and private secondary schools registered under the Ministry of Education, Malaysia (MOE). A scheduled school visit by the school health team was carried out to ensure HPV vaccination spaced at month 0, 1 and 6 were completed within the same year before school end in November.

\section{Consent approach}

Written parental consent was obtained prior to vaccination. The consent forms were distributed to parents through school teachers prior to scheduled vaccination visits. The parents returned the consent form to the school team. Whenever the children were refused immunization by their parents, the school health teams would call the parents to determine reasons for refusal and made are mark on the student registration form.

\section{Ethical issues}

Ethical issues surrounding HPV vaccination and parental rights to adequate information was not compromised in the process of obtaining parental written consent. Parents were provided with HPV vaccine information through print and electronic media to enable those making independent informed choices.

Compliance to religious requirement was fundamental to HPV vaccine uptake amongst the Muslim population in Malaysia. $\mathrm{MOH}$ worked with Malaysian religious authority in having an Islamic ruling (fatwa) on HPV vaccination. The ruling stipulates "Immunising women with HPV vaccine that has been determined to have no element of doubt in its content and will not harm the recipient, is permissible for the prevention of cervical cancer" [34, 35]. 


\section{Managing risk communication}

Introduction of HPV vaccine particularly involves supporting the acceptability of the vaccines to adolescent girls who may have little or no knowledge about cervical cancer and parents that may be suspicious of the vaccines, will give particularly if exposed to negative media attention and thus programs must proactively address communication requirements [36, 37]. Through an effective health communication programs, HPV vaccination was successfully introduced and found broad-based support from policy decision-makers, healthcare professionals, and the general public as well as by the target population [38].

\section{Social mobilisation and advocacy}

Electronic, printed and social media were the main communication channels employed in creating public awareness towards accepting HPV vaccination [39-41]. Major telecommunication stations, newspapers and magazines were engaged to air the HPV messages 5 months prior to starting the programme (Fig. 1). Multiple campaigns regarding the vaccines and its availability were constantly featured at prime time on main communication channels and on the bill board. Traditional and social media outlets were very active during the first 2 years of the launch. Information such as the programme website link was provided in every pamphlet and poster and also in electronic media. A specific tagline and a logo were created by Health Education Division, Department of Public Health, $\mathrm{MOH}$ for the female students to associate themselves with the HPV vaccination (Fig. 1).Negative feedback and reporting on HPV vaccination abroad and locally were closely monitored and addressed accordingly to alleviate fear among the public and the target population.

On the day of the vaccination, the school health nurses delivered a brief introduction on the HPV infection, cervical cancer, and HPV vaccine to the recipients. After the introduction, an assessment was carried out on health status to determine presence of illness or any contraindications for vaccination which require immunisation to be deferred to later dates. A guideline was developed by Family Health Development Division, $\mathrm{MOH}$ to carry out the mass vaccination [42]. The HPV injections were given by the community nurses. Relevant individual information on the vaccination were captured and documented in HPV vaccination registration forms and individual vaccination cards.

After the vaccination, recipients were observed for 20 min for any immediate adverse reactions. They were provided with an Adverse Event Following Immunisation (AEFI) monitoring form and vaccination card before returning to their classes. All recipients were advised to seek medical help if they experienced any suspected

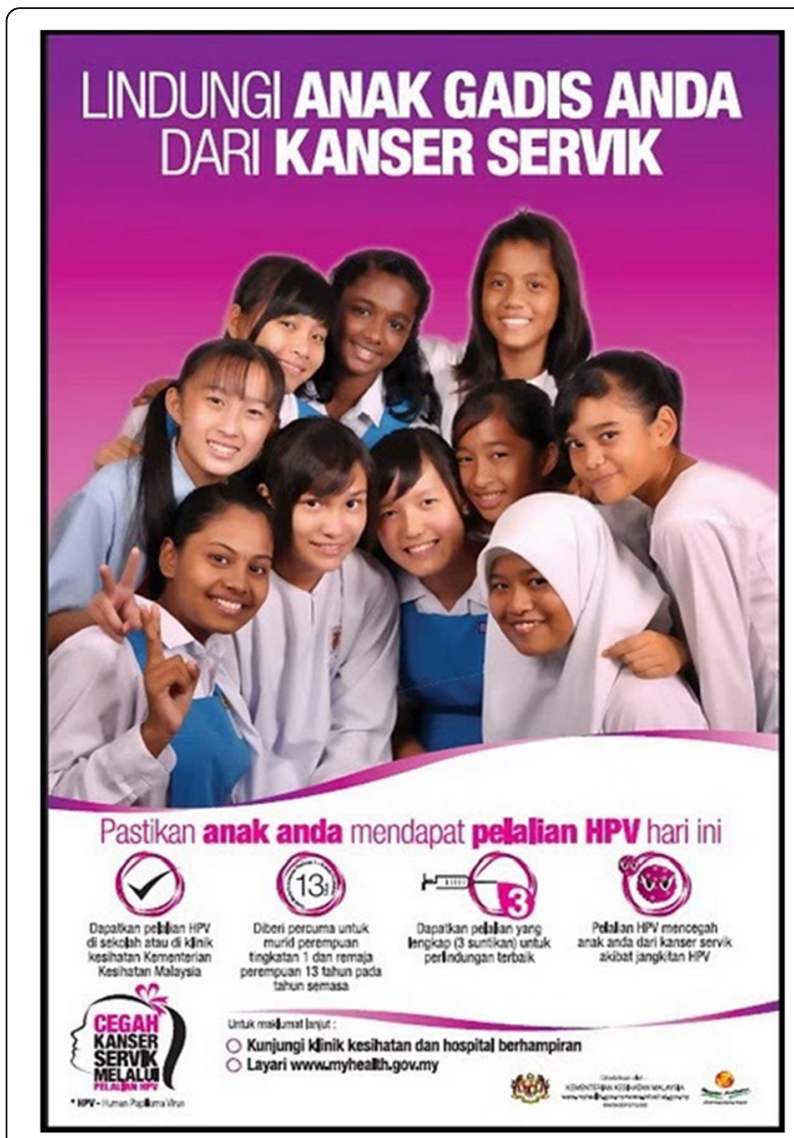

Fig. 1 Tagline (Translation "Lindungi Anak Gadis Anda dari Kanser Serviks": Protect Your Daughter from Cervical Cancer) (Translation "Pastikan anak anda mendapat pelalian HPV hari ini": Ensure your daughter receives HPV vaccination today) (Translation "Dapatkan pelalian HPV di sekolah atau di klinik kesihatan Kementerian Kesihatan Malaysia": Get the HPV vaccination in school or government health clinic, Ministry of Health Malaysia) (Translation "Diberi percuma untuk murid perempuan tingkatan 1 dan remaja perempuan 13 tahun pada tahun semasa": Given free of charge to form 1 school girl and adolescent girl aged 13 in the index year) (Translation "Dapatkan pelalian yang lengkap (3 suntikan) untuk perlindungan terbaik": Get complete HPV vaccination (3 injections) for best protection)(Translation "Pelalian HPV mencegah anak anda dari kanser servik akibat jangkitan HPV": HPV vaccination prevent your daughter from cervical cancer due to HPV infection) (Translation "Untuk maklumat lanjut: O Kunjungi klinik kesihatan dan hospital berhampiran atau Layari www.myhealth.gov.my": For further information: Visit nearest clinic and hospital or surf www.myhealth.gov.my)

adverse reactions. The AEFI monitoring forms were collected from students at school either on the following visits or at any contact with the health providers in accordance to guidelines [24].

\section{Results}

\section{Delivery of HPV vaccination}

Eligible criteria for HPV vaccination

Free vaccination was offered to eligible recipients (year seven) in Malaysia which was usually at the age of 13 in the index year. Only female year seven students are 
eligible to receive vaccination irrespective of their actual age. All recipients of the HPV vaccine were identified through school enrolment data obtained from education departments from each district in Malaysia. A total of 242,638recipients aged between 12 to 13 years studying in year seven were approached during the launch of the program in 2010. Approximately, 230,000 recipients were offered HPV vaccine annually by 646 school health teams throughout the country from 2010 to 2016.

\section{Monitoring indicators}

Parental consent, coverage by doses and vaccination completion were closely monitored as part of vaccination delivery indicators. Parental consent reflects the level of acceptance of the vaccine introduced. It was measured by the total number of parents consented for their child to be vaccinated over total number of year seven female student's enrolment. A total of 232,645 from 242,638 (95.9\%) parents consented to the immunisation in 2010. Subsequently, in 2011 a total of 229,021 from 234,668 (97.6\%) and in 2012 a total 232,705 from 237, 017 (98.2\%) were obtained from the parents. Throughout 2013, a total of 243,681 from 247,549 (98.4\%) parents gave consent for immunisation. In 2014, 2015 and 2016, a total of 226,253 from 229,739 (98.5\%), 220,789 from 224,761 (98.2\%) and 215,090 from 218,590 (98.4\%) parents consented to their child to be immunised respectively. Reasons for non-consent included unsure of vaccine safety, child has been immunised in private clinic and unable to retrieve consent forms from students. Figure 2 showed the percent of girls with parental consent who completed the vaccination.

\section{Vaccination coverage}

Vaccination coverage provides information on vaccination uptake in the total population, including those girls not in school and therefore not offered vaccination. It was measured by total number of recipients who received a complete immunisation course over estimated total number of female students (Fig. 3).

\section{Vaccination completion}

Completed vaccination refers to recipients completing 3 doses of HPV vaccination or 2 doses in 2015. It was observed that $93.35 \%$ students with parental consent completed their 3 doses of vaccination in 2010. It improved to $98.3 \%$ in 2011 and increased to $99.3,99.4$ and $99.6 \%$ in 2012, 2013 and 2014, 99.6\% from 2015 and 99.1\% from 2016 cohort who received 2 doses.

\section{Dose 1 completion}

First dose completion for 2010 was $99.5 \%$ for recipients with parental consent. The completion improved to 99.7, 99.8 and 99.9\% from 2012, 2013 and 2015 respectively but declined to $83 \%$ in 2016. Main reason for non-immunised among the consented were fear, absenteeism, claimed to have been immunised before and due to vaccine being charged to the students attending private sector schools in 2016.

\section{Dose 2 completion}

The completion rate for the second dose was slightly lower than the first dose. The completion of second dose was $98.9 \%$ in 2010 and increased above $99 \%$ in 2011 . The main reason stated by students for not continuing

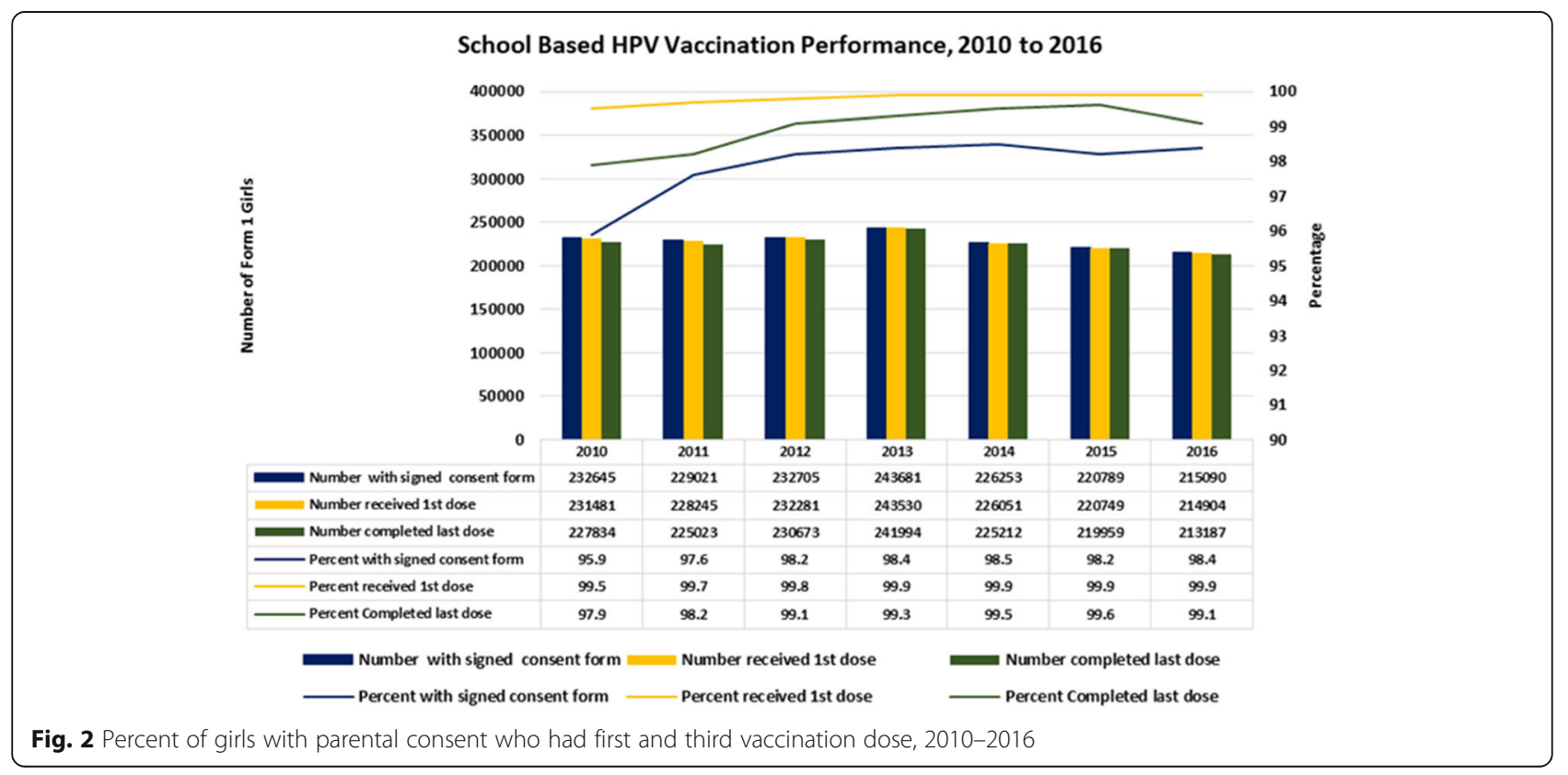


Coverage of HPV Vaccination for 13 Years Old in Malaysia 2010- 2016

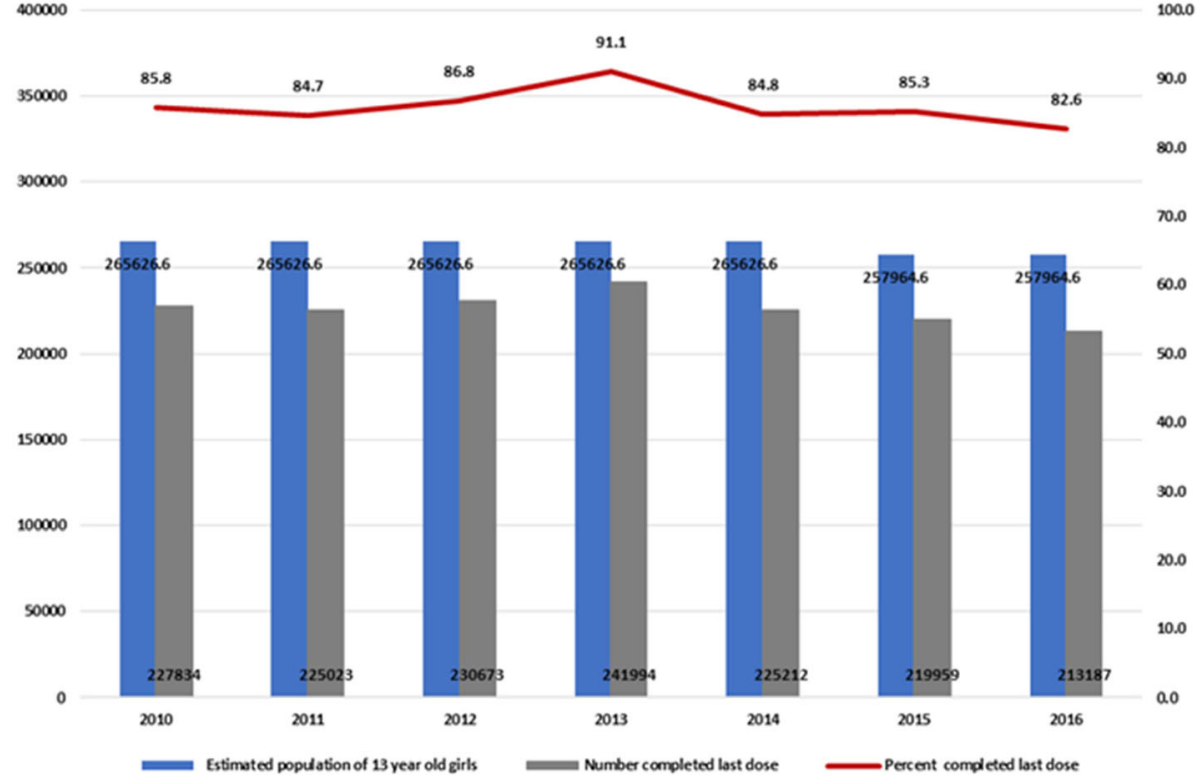

Fig. 3 Percent of 13 year old girls vaccinated, 2010-2016 *Source for all figures: Family Health Department, Ministry of Health Malaysia 2018

their vaccination course was the experience of side effects during first dose.

\section{Dose 3 completion}

Third dose completion rates showed a further drop of on average 0.5 to $1 \%$. The highest drop for the third dose was in 2010 from 98.9 to $97.9 \%$ while the lowest drop was $0.3 \%$ in 2014 . Third dose completion was not applicable in 2015 due to the two doses schedule. Reasons for not completing were similar to the reasons stated for the second dose.

\section{Vaccine safety}

Active adverse event following immunisation (AEFI) monitoring was introduced to create students and parental awareness on vaccine and vaccination safety. Any adverse event would be reported for every dose of immunisation. Active reporting was encouraged by providing an AEFI form to all recipients. Reports of recipients experiencing AEFI were collected and monitored by the Malaysian Adverse Drug Reactions Advisory Committee (MADRAC).

During the first year of implementation, the $\mathrm{MOH}$ managed to provide HPV vaccination services to almost $96 \%(231,869)$ of eligible recipients in all public, private and international secondary schools. The absence of mothers during vaccination in school did not reduce the HPV vaccination uptake among girls in Malaysia [19, 43]. Throughout the 5-year period, the $\mathrm{MOH}$ received AEFI reports at a rate of about 2 per 100,000 doses administered (7872 AEFI reports out of 3.9 million HPV vaccination doses) as shown in Table 2 . On average, two symptoms were notified in every report received. The main symptoms reported were itching, bruising or soreness at the administration site at $12184(72.3 \%)$ followed by headaches and giddiness at $2166(12.9 \%)$ and gastrointestinal disorder at 1461 (8.7\%).

\section{Discussion}

The World Health Organization recommends a school-based approach for effectively delivering HPV vaccine in countries that have a fairly high enrolment of girls in schools [44]. The Malaysian experience demonstrates one model and some of the essential elements that contributed to achieving success with such an approach. School-based programmes require a stable commitment of and strong collaboration between health and education authorities.

\section{Political will and commitment}

A sustainable national HPV vaccination programme is resource intensiveand requires a strong policyto ensure continuous financial support [45-47]. Advocacy plays a major role in shifting the political stakeholders' views towards the importance of cervical cancer prevention programme to reduce the incidence of cervical cancer through prophylactic HPV vaccine [46]. Advocacy efforts produced fruitful results and was reflected in 2007 which was done by sharing education information through 
Table 2 Notifications of Adverse events following immunisation (AEFI)

\begin{tabular}{llllllll}
\hline & 2010 & 2011 & 2012 & 2013 & 2014 & 2015 & 2016 \\
\hline Total dose of vaccine delivered & 689,490 & 679,924 & 692,530 & 728,604 & 677,131 & 440,754 & 428,091 \\
No. of AEFI reported & 412 & 3033 & 1831 & 1606 & 908 & 1095 & 656 \\
Percentage of AEFI reported & 0.06 & 0.45 & 0.26 & 0.22 & 0.13 & 0.25 & 0.15 \\
\hline
\end{tabular}

Source: National Pharmaceutical Regulatory Agency, Ministry of Health. 2018

multimedia coverage and cost effectiveness of HPV vaccine against cervical cancer $[29,48]$.

\section{Smart partnership with relevant stakeholders}

Partnerships across stakeholders are necessary for the development of relevant and effective strategies in addressing issues for maximum efficiency and positive impact of national HPV vaccination implementation [49, 50]. The existing relationship with the Ministry of Education (MOE) was an enabling factor in facilitation of voluntary parental consent through schools. Collaboration with MOE was strengthened at national, state, district and operational levels. Active monitoring by the personnel within MOE to all school principals to participate in the HPV vaccination program was done to enable the program to be conducted in systematic way and according to schedule. Interactive discussion between school administrative and school health teams was carried out regularly to ensure successful school immunization programme [51]. Regular discussions were held with relevant government agencies, professional bodies and non-government agencies to gain their continuous support and commitment.

While anticipating potential media threats, $\mathrm{MOH}$ utilized multipronged strategies to communicate the messages across the public. $\mathrm{MOH}$ had successfully engaged various subgroups to talk and discuss regarding the introduction of HPV immunization through print, electronic and social media (face book and twitter) and telephone hotline. Other activities carried out were rumours surveillance, public forums, health talks, print and electronic media campaigns. The messages were tailored to local cultural context, religion and information needs of parents, target population and general public and to alleviate fear and misconception about vaccine being new, and reinforce vaccine safety $[52,53]$.

\section{Conclusion}

School-based programmes require the stable commitment of and strong collaboration between health and education authorities. Two essential elements for such collaboration are policies and mechanisms. National policies and the corresponding managerial and operational mechanisms are the key elements for the school health programme to be successful. The approach used in Malaysian school-based immunisation program is recommended as it was able to deliver HPV vaccination with good coverage. The success of the implementation in Malaysia was due to careful program planning at national, states and district levels. Involvement of various stakeholders and gatekeepers facilitated the public acceptance of a new and potentially controversial vaccine. Highlighting the relationship of the vaccination and cervical cancer in the context of the Malaysian culture and religious belief further enhanced the uptake of vaccination in school. Periodic mass media campaigns created a positive supportive environment in changing beliefs and practices towards the new vaccine. Availability of health personnel to respond to public concerns further increased public confidence with the $\mathrm{MOH}$ new policy. Political will and a high-level commitment ensure the sustainability of the School-based HPV Vaccination Programme in Malaysia.

\section{Abbreviations}

AEFI: Adverse effects following immunization; DNA: Deoxyribonucleic acid; HPV: Human papilloma virus; MADRAC: Malaysian adverse drug reaction advisory committee; MOE: Ministry of education; $\mathrm{MOH}$ : Ministry of health; STI: Sexual transmitted illness; WHO: World Health Organization

\section{Acknowledgements}

We thank the Director General of Health, Ministry of Health, Malaysia for permission to publish this report. We thank The Ministry of Education, Malaysia for their support in making the program a success. Our appreciation goes to everyone at all schools who were involved with this program.

\section{Funding}

The study was funded by Ministry of Health, Malaysia through Family Health Development Division which was involved with the initial conception of the National HPV Programme and identification of recipients for HPV vaccination. Analysis and interpretation of the data and writing the manuscript were done together with Institute of Public Health, Ministry of Health Malaysia.

\section{Availability of data and materials}

The dataset during the current study is available from the archive of Family Health Development Division through corresponding author upon reasonable request with permission of Ministry of Health, Malaysia.

\section{Authors' contributions}

NAM developed the theory and performed the computations, wrote draft manuscript and contributed to the final manuscript. SNB is Manager of the HPV programme in the Ministry of Health $(\mathrm{MoH})$ and contributed to the final manuscript. SJ was Director of the MoH Family Health Development Division programme and conceived the idea and contributed to the final manuscript. $\mathrm{RJ}$ developed and discussed the strategies for the programme and contributed to the final manuscript. PST discussed the results and contributed to the final manuscript. NM developed the theory and wrote the draft manuscript, discussed the results and contributed to the final manuscript. NAL developed the theory and discussed the results and contributed to the final manuscript. TA verified the results, supervised the findings of this work and contributed to the final manuscript. LHS verified the results, supervised the findings of this work and contributed to the final manuscript. SM Discussed the result and contributed to the final manuscript and contributed to the final manuscript. All authors read and approved the final manuscript. 


\section{Ethics approval and consent to participate}

For developing this report, formal ethics approval was not required as the analysis was mainly a retrospective programme evaluation conducted at the policy and programme level. The report was based on existing data and documentation with any data aggregated at the population level. All data from key informant interviews and stakeholder meetings was analyzed in the aggregate and quotes anonymized, except where approval to quote was specifically provided. Written parental consent was obtained prior to vaccination. The consent forms were distributed to parents through school teachers prior to scheduled vaccination visits. The parents returned the consent form to the school team. Whenever the children were refused immunization by their parents, the school health teams would call the parents to determine reasons for refusal and made a remark on the student registration form.

\section{Consent for publication}

This manuscript has obtained the approval for publication from Director General of Health, Ministry of Health Malaysia. For the purpose of this reports, consent from the people portrayed in Fig. 1 was obtained prior to starting the programme.

\section{Competing interests}

All authors read and understood the policy on declaration of interest and declare that they have no competing interest.

\section{Publisher's Note}

Springer Nature remains neutral with regard to jurisdictional claims in published maps and institutional affiliations.

\section{Author details}

'Institute for Public Health, Ministry of Health, Kuala Lumpur, Malaysia. ${ }^{2}$ Family Health Development Division, Ministry of Health, Kuala Lumpur, Malaysia. ${ }^{3}$ Department of Community Medicine, International Medical University, Kuala Lumpur, Malaysia. ${ }^{4}$ Faculty of Science and Technology, Open University Malaysia, Kuala Lumpur, Malaysia. ${ }^{5}$ Disease Control Division, Ministry of Health, Kuala Lumpur, Malaysia. ${ }^{6}$ Office of Deputy Director General of Health (Public Health), Ministry of Health, Putrajaya, Malaysia. ${ }^{7}$ Office of Deputy Director General of Health (Research and Technical Support), Ministry of Health, Putrajaya, Malaysia.

\section{Received: 11 September 2017 Accepted: 11 December 2018} Published online: 22 December 2018

\section{References}

1. Center for Disease Control and Prevention. Genital HPV infection - fact sheet. 2016. Available at http://www.cdc.gov/std/hpv/stdfact-hpv.htm. Accessed on 13 Jan 2017.

2. Lin Yang, ShuanghuaXie, Xiaoshuang Feng, Yuheng Chen, Tongzhang Zheng, Min Dai, Cindy Ke Zhou, Zhibin Hu, Ni Li, Dong Hang (2015); Worldwide Prevalence of Human Papillomavirus and Relative Risk of Prostate Cancer. Available at http://www.nature.com/articles/srep14667. Accessed 18 Jan 2017.

3. WHO 2016; Immunization, Vaccines and biologicals. Available at http:// www.who.int/immunization/diseases/hpv/en/. Accessed 18 Jan 2017

4. Menon S, van den Broeck D, Rossi R, Ogbe E, Mabeya H. Multiple HPV infections in female sex workers in Western Kenya: implications for prophylactic vaccines within this subpopulation; Menon et al. Infect Agents Cancer. 2017;12(2). https://doi.org/10.1186/s13027-016-0114-5.

5. Ng'andwe C, Lowe JJ, Richards PJ, Hause L, Wood C, Angeletti PC. Thedistribution of sexually-transmitted human papillomaviruses in HIV positiveand negative patients in Zambia. Africa BMC Infect Dis. 2007;7:77. https://doi.org/10.1186/1471-2334-7-77.

6. Center for Disease Control and Prevention (CDC). Human papilloma virus associated cancers - United States, 2004-2008. MMWR Morb Mortal Wkly Rep. 2012;61:258-61.

7. World Health Organization. Cervical Cancer at http://www.who.int/cancer/ prevention/diagnosis-screening/cervical-cancer/en/ Assessed on 30 Oct 2018

8. Haghshenas M, Golini-Moghaddam T, Rafiei A, et al. Prevalence and type distribution of high-risk human papillomavirus in patients with cervical cancer: a population-basedstudy. Infect Agent Cancer. 2013;8:20.
9. Sreedevi A, Javed R, Dinesh A. Epidemiology of cervical cancer with special focus on India. Int J Women's Health. 2015;7:405-14.

10. De Vuyst $H$, Alemany L, Lacey $C$, et al. The burden of human papillomavirus infections and related diseases in sub-Saharan Africa. Vaccine. 2013;31(05): F32-46. https://doi.org/10.1016/j.vaccine.2012.07.092.

11. Maranga IO, Hampson L, Oliver AW, et al. Analysis of factors contributing to the low survival of cervical cancer patients undergoing radiotherapy in KenyaHawkins SM, ed. PLOS One. 2013;8(10):e78411. https:/doi.org/10.1371/journal.pone.0078411.

12. Zaridah S. A review of cervical cancer research in Malaysia. Med J Malaysia. 2014; 69:33-41 Available at https://www.ncbi.nlm.nih.gov/pubmed/25417949.

13. Azizah A, Norsaleha IT, Noor Hashimah A, Asmah ZA, Mastulu W. Malaysian National Cancer Registry Report 2007-2011. Putrajaya: Malaysia Cancer Statistics, Data and Figure, National Cancer Institute, Ministry of Health; 2017. p. 50-2.

14. Bruni L, Albero G, Serrano B, Mena M, Gómez D, Muñoz J, Bosch FX, et al. Human papillomavirus and related diseases in MalaysiaSummary Report: ICO/IARC Information Centre on HPV and Cancer (HPV Information Centre). Human Papillomavirus and Related Diseases in Malaysia. Summary Report; 2018. Available at http://www.hpvcentre.net/statistics/reports/MYS.pdf. Accessed 14 Dec 2018.

15. Chesson HW, Ekwueme DU, Saraiya M, Watson M, Lowy DR, Markowitz LE. Estimates of the annual direct medical costs of the prevention and treatment of disease associated with human papillomavirus in the United States. Vaccine. 2012; 30(42):6016-9. https://doi.org/10.1016/j.vaccine.2012.07.056 Epub 2012 Aug 4.

16. Howell-Jones R, Bailey A, Beddows S, et al. Multi-site study of HPV typespecific prevalence in women with cervical cancer, intraepithelial neoplasia and normal cytology, in England. Br J Cancer. 2010;103(2):209-16. https:// doi.org/10.1038/sj.bjc.6605747.

17. National Cancer Institute 2016; Cancer Screening Overview (PDQ $\left.{ }^{\oplus}\right)$-Health Professional Version. Available at https://www.cancer.gov/about-cancer/ screening/hp-screening-overview-pdq. Accessed 18 Jan 2017.

18. World Health Organisation. Human papillomavirus vaccines: WHO position paper, may 2017. Wkly Epidemiol Rec. 2017;92:241-68.

19. Sharifa Ezat WP, Rozita H, Jamsiah M, Ahmad Zailani Hatta MD, Aqmar Suraya S, Azlin A. National HPV Immunisation Programme: Knowledge and Acceptance of Mothers Attending an Obstetrics Clinic at a Teaching Hospital, Kuala Lumpur. Asian Pacific J Cancer Prev. 2013;14(5): 2991-99.

20. Department of statistics. Malaysia. Population \& Demography. Available at: https:// www.dosm.gov.my/v1/index.php?r=column/ctwoByCat\&parent_id=115\&menu_ id=LOpheU43NWJwRWVZZkIWdzQ4TIhUUT09. Accessed 30 Aug 2018.

21. Cheong SM, Mohamad Nor NS, et al. Improvement of health literacy and intervention measurements among low socio-economic status women: findings from the MyBFF@home study. BMC Womens Health. 2018;18(Suppl 1):018-0596. https://doi.org/10.1186/s12905-018-0596-y.

22. Norrafizah J, Nor Asiah M, Suraiya SM, et al. Assessment of health literacy among people in a rural area in Malaysia using newest vital signs assessment. Br J Educ Soc Behav Sci. 2016;16(2):1-7. https://doi.org/10.9734/ BJESBS/2016/25737.

23. Ashtarian H, Mirzabeigi E, Mahmoodi E, Khezeli M. Knowledge about cervical cancer and pap smear and the factors influencing the pap test screening among women. Int J Commun Based Nurs Midwifery. 2017:5(2):188-95.

24. Buang SN, Jahis R. Lessons learned: building the school-based HPV program in Malaysia and opportunities for piggybacking. Bangkok: Asia Dengue Summit Shangri La Hotel; 2016. Available at: https://adva.asia/ads/day2/ Rohani-Jahis+Saidatul-Norbaya-Buang.pdf. Accessed 18 Jan 2017

25. Were E, Nyaberi Z, Buziba N. Perceptions of risk and barriers to cervical cancer screening at Moi teaching and referral hospital (MTRH), Eldoret, Kenya. Afr Health Sci. 2011;11(1):58-64.

26. Sharifa Ezat WP, Syed MA. Affordability of HPV vaccine in developing countries. Malay J Public Health Med. 2011;11(1):1-5.

27. U.S. Food and Drug Administration. June 8, 2006 Approval Letter - Human Papillomavirus Quadrivalent (Types 6, 11, 16, 18) Vaccine, Recombinant. Available at http://www.fda.gov/BiologicsBloodVaccines/Vaccines/ ApprovedProducts/ucm111283.htm. Accessed 18 Jan 2017.

28. U.S. Food and Drug Administration. May 5, 2010 Approval letter - Cervarix. Available at http://www.fda.gov/BiologicsBloodVaccines/Vaccines/ ApprovedProducts/ucm212571.htm. Accessed 18 Jan 2017.

29. Kim JJ, Ortendahl J, Goldie SJ. Cost-effectiveness of HPV vaccination and cervical cancer screening in women over age 30 in the United States. Ann Intern Med. 2009;151(8):538-45. 
30. Tota JE, Ramana-Kumar AV, El-Khatib Z, Franco EL. The road ahead for cervical cancer prevention and control. Curr Oncol. 2014;21(2):e255-64. https://doi.org/10.3747/co.21.1720.

31. Gandhi G, Lydon P. Updating the evidence base on the operational costs of supplementary immunization activities for current and future accelerated disease control, elimination and eradication efforts. BMC Public Health. 2014;14:67. https://doi.org/10.1186/1471-2458-14-67.

32. World Health Organization. Immunization, Vaccines and Biologicals; Human papillomavirus (HPV).Available at http://www.who.int/immunization/ diseases/hpv/en/. Accessed 18 Jul 2017.

33. Meites E, Kempe A, Markowitz LE. Use of a 2-dose schedule for human papillomavirus vaccination - updated recommendations of the advisory committee on immunization practices. MMWR Morb Mortal Wkly Rep. 2016; 65:1405-8. https://doi.org/10.15585/mmwr.mm6549a5.

34. Isa NM, Baharuddin A, Man S, Chang LW. Bioethics in the Malay-Muslim Community in Malaysia: a study on the formulation of fatwa on genetically modified food by the National Fatwa Council. Dev World Bioeth. 2015;15(3); 143-51. https://doi.org/10.1111/dewb.12057. Available at https://umexpert. um.edu.my/file/publication/00002819_107753.pdf. Accessed 17 July 2017.

35. The Ruling on Using Human Papilloma Virus Vaccine (HPV); The 92th Muzakarah (Conference) of the Fatwa Committee National Council of Islamic Religious Affairs Malaysia held on 15-17 December 2010. Available at http://irep.iium.edu.my/16091/1/HALAL_PHARMACEUTICAL-2011.pdf. Accessed 17 Jul 2017

36. Hilton S, Hunt K, Langan M, Bedford H, Petticrew M. Newsprint media representations of the introduction of the HPV vaccination programme for cervical cancer prevention in the UK (2005-2008). Soc Sci Med. 2010;70: 942-50. https://doi.org/10.1016/j.socscimed.2009.11.027.

37. Remes P, Selestinea V, Changaluchac J, Ross DA, Wight D, de Sanjosée S, et al. A qualitative study of HPV vaccine acceptability among health workers, teachers, parents, female pupils, and religious leaders in Northwest Tanzania. Vaccine. 2012;30:5363-7.

38. Sherris J, Friedman A, Wittet S, Davies P, Marc Steben M, Saraiya M. Education, training, and communication for HPV vaccines. Vaccine. 2006; 24S3:210-8. https://doi.org/10.1016/j.vaccine.2006.05.124.

39. Kabakama S, Katherine E, Gallagher KE, Howard N, Mounier-Jack S, HED B, et al. Social mobilisation, consent and acceptability: a review of human papillomavirus vaccination procedures in low and middle-income countries. BMC Public HealthBMC series - open, inclusive and trusted. 2016;16:834. https://doi.org/10.1186/s12889-016-3517-8

40. Chaturvedi S. Vaccines. Social mobilization, or any other game changer: polio eradication is an unfinished narrative. Indian J Community Med. 2013; 38(2):67-9. https://doi.org/10.4103/0970-0218.112429.

41. Weiss WM, Choudhary M, Solomon R. Performance and determinants of routine immunization coverage within the context of intensive polio eradication activities in Uttar Pradesh, India: social mobilization network (SM net) and Core Group polio project CGPP. BMC Int Health Hum Rights. 2013; 13(25). https://doi.org/10.1186/1472-698X-13-25.

42. Buku Panduan PelaksanaanPelalian HPV UntukParamedik. Available at : http://fh.moh.gov.my/v3/index.php/component/jdownloads/send/36-sektorkesihatan-sekolah/204-hpv?ltemid=0. Accessed 27 Jul 2018.

43. Kadis JA, McRee AL, Gottlieb SL, Lee MR, Reiter PL, Dittus PJ, et al. Mothers' support for voluntary provision of HPV vaccine in schools. Vaccine. 2011; 29(14):2542-7. https://doi.org/10.1016/j.vaccine.2011.01.067.

44. WHO. Human papillomavirus vaccines: WHO position paper, may $2017-$ recommendations. Vaccine. 2017;35(43):5753-5.

45. Hardt K, Bonanni P, King S, Santos Jl, El-Hodhod M, Zimet GD, et al. Vaccine strategies: Optimising outcomes. Vaccine. 2016;34:6691-9.

46. Preiss S, Garçon N, Cunningham AL, Strugnell R, Friedland LR. Vaccine provision: delivering sustained \& widespread use. Vaccine. 2016;34:6665-71.

47. Sherris J, Agurto I, Arrossi S, Dzuba I, Gaffikin L, Herdman C, et al. Advocating for cervical cancer prevention. Int J Gynecol Obstet. 2005;89:46-54.

48. Ogembo JG, Manga S, Nulah K, Foglabenchi LH, Perlman S, Wamai RG, et al. Achieving high uptake of human papillomavirus vaccine in Cameroon: lessons learned in overcoming challenges. Vaccine. 2014;32:4399-403.

49. Beer H, Hibbitts S, Brophy S, Rahman MA, Waller J, Paranjothy S. Does the HPV vaccination programme have implications for cervical screening programmes in the UK? Vaccine. 2014;32(16):1828-33. https://doi.org/10. 1016/j.vaccine.2014.01.087.

50. Setiawan D, Kotsopoulos N, Wilschut JC, Postma MJ, Connolly MP. Assessment of the broader economic consequences of HPV prevention from a government-perspective: a fiscal analytic approachNatarajaseenivasan K, ed. PLoS One. 2016;11(8):e0160707. https:// doi.org/10.1371/journal.pone.0160707.

51. World Health Organization 2014. Principles and considerations for adding a vaccine to a national immunization programme: From Decision to Implementation and Monitoring. Available at http://apps.who.int/iris/ bitstream/10665/111548/1/9789241506892_eng.pdf. Accessed 5 Jun 2017.

52. World Health Organization. Global Vaccine Safety. The Global Vaccine Safety Initiative (GVSI). 2011. Available at http://www.who.int/vaccine_safety/ initiative/en/. Accessed 18 Jul 2017

53. Zimet GD, Rosberger Z, Fisher WA, Perez S, Stupiansky NW. Beliefs, behaviors and HPV vaccine: correcting the myths and the misinformation. Prev Med. 2013;57(5):414-8. https://doi.org/10.1016/j.ypmed.2013.05.013.

\section{Ready to submit your research? Choose BMC and benefit from:}

- fast, convenient online submission

- thorough peer review by experienced researchers in your field

- rapid publication on acceptance

- support for research data, including large and complex data types

- gold Open Access which fosters wider collaboration and increased citations

- maximum visibility for your research: over $100 \mathrm{M}$ website views per year

At BMC, research is always in progress.

Learn more biomedcentral.com/submissions 